\title{
Distribution of mesopelagic decapod Crustacea in and around a warm-core eddy in the Tasman Sea
}

\author{
F. B. Griffiths and Stephen B. Brandt \\ Division of Fisheries Research, CSIRO Marine Laboratories, P. O. Box 21, Cronulla, NSW 2230, Australia
}

\begin{abstract}
Nocturnal distributions of mesopelagic penaeid, sergestid, and carid crustaceans were determined in the upper $300 \mathrm{~m}$ inside, outside and at the edge of warm-core eddy $\mathrm{F}$ in December 1978. The 3 sites sampled represent 3 different domains within the Tasman sea water mass. Twenty-five species (2025 specimens) were caught. Systellaspis debilis, Funchalia villosa and Sergestes stimulator were most abundant inside the eddy, whilst Sergestes disjunctus was most abundant outside. Acanthephyra quadrispinosa, Gennadas gilchristi, Sergestes armatus, $S$. disjunctus, and Sergia prehensilis were more numerous in cold $\left(<16^{\circ} \mathrm{C}\right)$ water, while Funchalia villosa was more numerous in warm water. The abundance of Oplophorus spinosus, S. debilis, S. armatus, Sergestes corniculum, S. disjunctus and $S$. prehensilis increased with depth. Three communities, corresponding to the outside, inside, and edge domains, were found. $O$. spinosus, $S$. prehensilis, and $S$. debilis were the dominant species in this study ( $72.2 \%$ of the total individuals) and all had evidence of population differences across the eddy boundary. $S$. prehensilis and $O$. spinosus were generally larger outside the eddy and tissue carbon levels and carbon/nitrogen levels were higher at the eddy edge than elsewhere. Proportionately more male and female $S$. prehensilis and female $O$. spinosus were in breeding condition outside the eddy and at the eddy edge than inside the eddy. Fecundity of $O$. spinosus was also higher outside the eddy. S. debilis females were larger at the eddy edge, but the proportion of breeding females was greatest inside the eddy. These differences are discussed in relation to the different thermal environments of the domains.
\end{abstract}

\section{INTRODUCTION}

Eddies or rings are common features of major western boundary currents including the Gulf Stream (Fuglister, 1972), East Australian (Andrews and ScullyPower, 1976), Kuroshio (Tomosada, 1978) and Somali (Bruce, 1979) currents. Recent work shows that much of the mesoscale variability in plankton distribution in the western North Atlantic ocean is due to the existence of cold-core rings shed by the Gulf Stream (Wiebe et al., 1976, Boyd et al., 1978, Ortner et al., 1978, Wiebe and Boyd, 1978, Ortner et al., 1979, the Ring Group, 1981) and that the physical and biological properties of the Slope water core of a cold-core ring are gradually replaced by those of the Sargasso Sea. The mechanisms of these replacements are believed to be horizontal mixing in the mixed layer, and exchange due to movement of water into and out of the ring below $400 \mathrm{~m}$ (Wiebe and Flierl, in press). Brandt and Wadley, (1981) believe biological factors may also be affecting communities in warm core rings.
Warm-core eddies form an important part of the circulation in the western Tasman Sea. They have diameters of 200 to $300 \mathrm{~km}$, extend to $1500 \mathrm{~m}$ depth (Hamon, 1965), and form when a meander of the southward flowing East Australian Current (EAC) breaks off to form a closed eddy (Nilsson and Cresswell, 1981). These authors have shown that eddies can move at least $0.15 \mathrm{~m} \mathrm{~s}^{-1}\left(13 \mathrm{~km} \mathrm{~d}^{-1}\right)$ and persist for between 500 and $800 \mathrm{~d}$ if they are not recaptured by the EAC.

Warm-core Eddy $F$ was formed by the subdivision of a larger eddy, Eddy D, between May and September 1978 (Tranter et al., 1979; Brandt, 1981). Eddy D originated as a meander of the EAC in February 1978 (Boland and Church, 1981). Eddy F moved in a southerly direction between September 1978 and February 1979 , and was centred at $36^{\circ} 30^{\prime} \mathrm{S}, 151^{\circ} 30^{\prime} \mathrm{E}$ on 25 February 1979 (Nilsson et al., 1982). This eddy was not followed after February 1979 but may have decayed via upwelling from below the seasonal thermocline (Nilsson and Cresswell, 1981).

A generalized circulation pattern for the Coral and 
Tasman Seas is given in Fig. 1. Briefly, the EAC forms north of $25^{\circ} \mathrm{S}$ and flows south near the eastern Australian coast until it swings east between $30^{\circ}$ and $34^{\circ} \mathrm{S}$ and forms the Tasman Front. The EAC and the Tasman Front form the boundary between the Coral and Tasman Seas. The eddy and the Coral Sea are areas of higher dynamic height than the Tasman Sea. A more detailed discussion of the circulation in the Coral and Tasman Seas is given by Nilsson and Cresswell (1981) and references cited therein.

The physical and biological environments of warm-

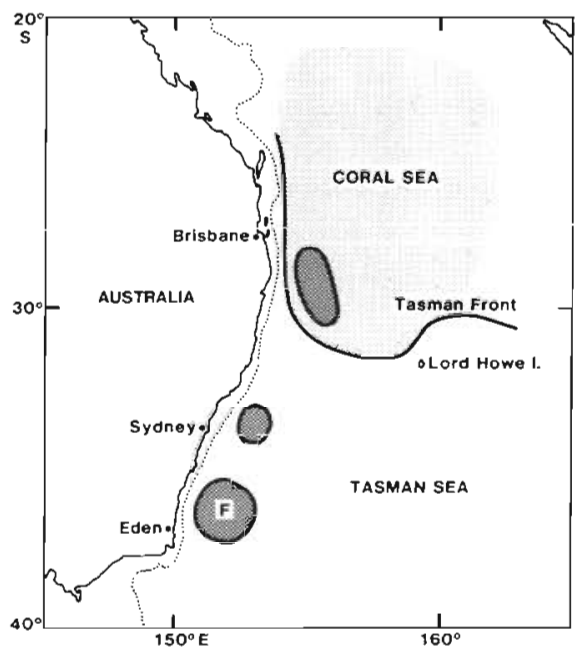

Fig. 1. Generalized circulation patterns in Coral and Tasman Seas, November/December 1978. The East Australian Current (heavy line) forms the Tasman front as it moves eastwards and separates Coral $\left(\mathrm{T}_{250}>17^{\circ} \mathrm{C}\right)$ and Tasman Seas $\left(\mathrm{T}_{250}<17^{\circ} \mathrm{C}\right)$. Shaded areas: highest dynamic height. Based on data from cruises in November and December 1978. Boundaries east of $156^{\circ}$ are largely conjectural core eddy Eddy $F$ differed from both the surrounding Tasman Sea and the EAC. The major physical differences were the formation of an isothermal core in the eddy by surface cooling and convective overturn during winter 1978 (Nilsson and Cresswell, 1981) and the different distribution of temperature and salinity with depth (Fig. 2). The major chemical difference was in nutrient cycling (Scott, 1978). The biological differences include phytoplankton levels (Tranter et al., 1980a) and species composition (Jeffrey and Hallegraeff, 1980), copepod species distributions (Tranter et al., in press), midwater fish community structure and distribution (Brandt, 1981) and mesopelagic squid distribution (Brandt, in press).

Mesopelagic decapods were sampled at a site inside, at the edge of and outside warm-core Eddy F. Each site was in a different domain (Dodimead et al., 1963) of the Tasman Sea water mass. The 2 questions posed in this study were: (1) Was there a separate decapod community in each domain? (2) Did size, reproduction, and chemical composition of selected species reflect the different physical and biological environments of the different domains of the Tasman Sea water mass?

\section{METHODS}

\section{Study area}

Warm-core Eddy $\mathrm{F}$ was centred at $36^{\circ} 30^{\circ} \mathrm{S}, 151^{\circ} 42^{\prime} \mathrm{E}$ in the Tasman Sea (Fig. 3) during the sampling period 1 to 10 December 1978 . The vertical thermal structure of Eddy $F$ was mapped to $450 \mathrm{~m}$ using expendable bathythermographs (XBTs): Brandt (1981) gives the $\mathrm{XBT}$ positions. Detailed salinity and temperature pro-

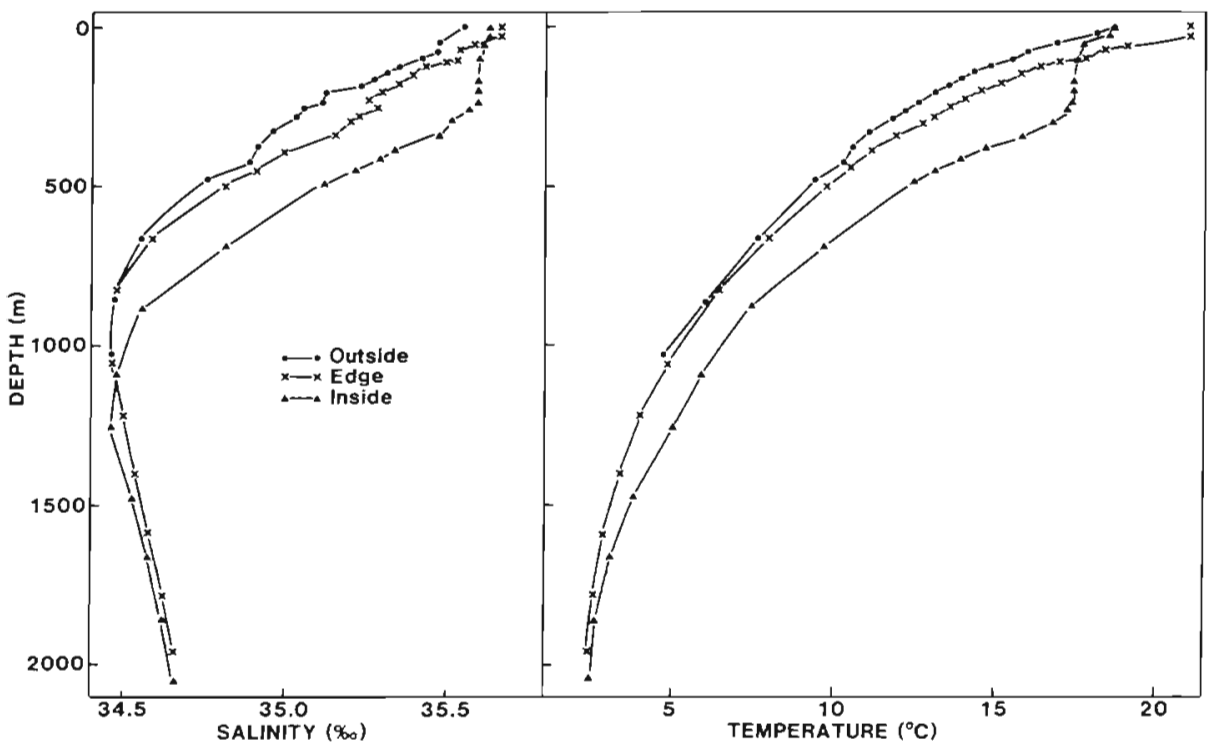

Fig. 2. Salinity and temperature profiles from hydrology stations inside (302, Fig. 3), outside (296) and at the edge (305) of Eddy $F$ 


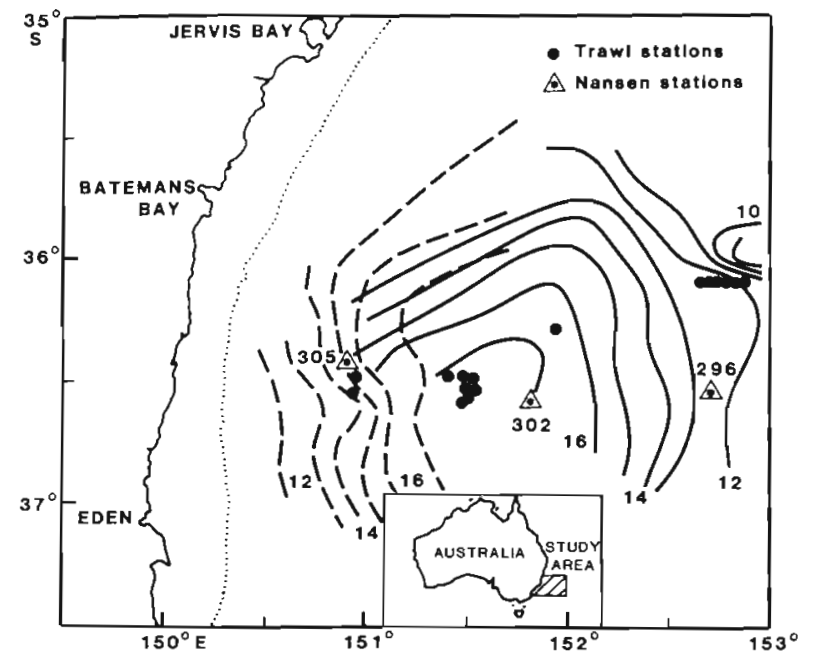

Fig. 3. Location of trawl and hydrology (Nansen) stations relative to temperature at $250 \mathrm{~m}$ between 28 November and 4 December (solid lines) and 8-13 December 1978 (broken lines). (After Brandt, 1981, modified)

files were taken at three stations using reversing Nansen bottles at $25 \mathrm{~m}$ intervals from the surface to $300 \mathrm{~m}$, at $50 \mathrm{~m}$ intervals to $500 \mathrm{~m}$, and at $200 \mathrm{~m}$ intervals to either $1100 \mathrm{~m}$ or $2000 \mathrm{~m}$ during 1 to 7 Decemter 1978 .

\section{Faunal collections}

Animals were collected using the FRV Courageous and a 308 meshes X $800 \mathrm{~mm}$ Engel midwater trawl having a $10 \mathrm{~mm}$ mesh liner in the cod end. The mouth area of this net is about $450 \mathrm{~m}^{2}$. A Simrad FB trawl eye mounted on the headrope of the trawl provided a continuous record of trawl depth, trawl vertical opening (about $12 \mathrm{~m}$ ) and water temperature. Horizontal tows of $30 \mathrm{~min}$ duration were made at depths of approximately $50 \mathrm{~m}, 150 \mathrm{~m}$, and $250 \mathrm{~m}$ at a speed of $1.5 \mathrm{~m} \mathrm{~s}^{-1}$. Three sampling sites were defined on the basis of the temperature at $250 \mathrm{~m}\left(\mathrm{~T}_{250}\right):<14{ }^{\circ} \mathrm{C}$, outside the eddy; 14 to $16^{\circ} \mathrm{C}$, eddy edge; and $>16^{\circ} \mathrm{C}$, inside the eddy (Table 1). Boland (1973) and Nilsson (1977) found that the fastest surface currents were at the eddy edge, above a temperature of $15^{\circ} \mathrm{C}$ at $250 \mathrm{~m}$. Samples were allocated to one of these sites on the basis of the $T_{250}$ measured by an XBT immediately before each sample was collected. At least 2 samples were taken at each of the 3 depths inside and outside the eddy, and at $250 \mathrm{~m}$ in the eddy edge. No crustacean samples were collected using the Engel trawl from $50 \mathrm{~m}$ and $150 \mathrm{~m}$ at the eddy edge. Brandt (1981) has discussed the limitations of this sampling program and the contamination problem caused by using a nonclosing trawl. The sampling order for the three depths at each site was chosen at random between $30 \mathrm{~min}$ after sunset and $30 \mathrm{~min}$ before sunrise. Crustacea were sorted from the samples on board ship. The mesopelagic decapods from one $250 \mathrm{~m}$ sample at each site were frozen at $-30^{\circ} \mathrm{C}$ within $1 \mathrm{~h}$ of the catch coming on board, and animals from all other samples were fixed in borax buffered $4 \%$ formaldehyde. Only night samples are discussed in this paper since only 6 decapods (Oplophorus spinosus) were caught in the 18 daytime samples.

Table 1. Trawl station information and biomass (g) of crustaceans. All samples taken between sunset (1959 to $2009 \mathrm{~h}$ ) and sunrise (0539 h) Australian Eastern Summer Time. New, first quarter and full moon occurred on 1 December, 7 December and 12 December, respectively. Geographic coordinates of trawl stations given in Brandt (1981)

\begin{tabular}{|c|c|c|c|c|c|c|c|c|c|}
\hline \multirow[t]{2}{*}{ Position } & \multirow{2}{*}{$\begin{array}{l}\mathrm{T}_{250} \\
\left({ }^{\circ} \mathrm{C}\right)\end{array}$} & \multirow{2}{*}{$\begin{array}{l}\text { Depth } \\
(\mathrm{m})\end{array}$} & \multirow{2}{*}{$\begin{array}{c}\text { Temp. } \\
\left({ }^{\circ} \mathrm{C}\right)\end{array}$} & \multirow{2}{*}{$\begin{array}{c}\text { Time } \\
\text { (h) }\end{array}$} & \multirow{2}{*}{$\begin{array}{l}\text { Date } \\
\text { Dec. }\end{array}$} & \multirow[b]{2}{*}{ Moonset } & \multicolumn{3}{|c|}{ Crustacean biomass (g) } \\
\hline & & & & & & & Carids & Penaeids & Sergestids \\
\hline \multirow[t]{7}{*}{ Inside eddy } & 17.4 & 32 & 18.3 & 2350 & 1 & 2110 & 0 & 165.1 & 0 \\
\hline & 17.3 & 45 & 18.1 & 2050 & 8 & 0152 & 6.4 & 101.1 & 1.2 \\
\hline & 17.4 & 50 & 18.0 & 0120 & 9 & 0228 & 10.5 & 6.1 & 0.5 \\
\hline & 17.3 & 155 & 17.5 & 2150 & 8 & & 81.7 & 27.9 & 12.3 \\
\hline & 17.4 & 158 & 17.4 & 0015 & 9 & & 139.7 & 16.6 & 23.1 \\
\hline & 17.3 & 255 & 17.3 & 2305 & 8 & & 92.3 & 25.5 & 22.7 \\
\hline & 17.3 & 255 & 17.3 & 0240 & 9 & & 220.8 & 28.4 & 52.8 \\
\hline \multirow[t]{2}{*}{ Eddy edge } & 15.7 & 245 & 15.8 & 0105 & 10 & 0304 & 95.7 & 6.2 & 11.9 \\
\hline & 15.7 & 260 & 15.6 & 2345 & 9 & & 44.0 & 11.8 & 50.5 \\
\hline \multirow[t]{6}{*}{ Outside eddy } & 11.3 & 52 & 17.5 & 0315 & 3 & 2303 & 0 & 2.6 & 0 \\
\hline & 11.5 & 55 & 17.5 & 0150 & 3 & & 0 & 0 & 0 \\
\hline & 12.2 & 150 & 13.4 & 0005 & 3 & & 103.9 & 5.2 & 164.0 \\
\hline & 11.3 & 152 & 12.8 & 0420 & 3 & & 40.8 & 0 & 2.9 \\
\hline & 13.2 & 255 & 13.1 & 2130 & 2 & 2209 & 16.1 & 9.6 & 151.4 \\
\hline & 12.5 & 255 & 12.4 & 2250 & 2 & & 97.8 & 9.7 & 160.3 \\
\hline
\end{tabular}




\section{Abundance, distribution and community structure}

Decapods were identified using keys in Yaldwyn (1957), Kensley (1968, 1971a, b, 1972) and Crosnier and Forest (1973). The wet weight of each species in each sample was measured about 15 mo after preservation to determine the total biomass and biomass dominants. Biomass comparisons for each major taxon (carids, penaeids, and sergestids) were made between the inside and outside sites (all depths combined) and among $250 \mathrm{~m}$ samples taken inside, at the edge, and outside of the eddy by summing the individual species weights

Mills (1969) defined a community as 'a group of organisms occurring in a particular environment, presumably interacting with each other and with the environment, and separable by means of ecological survey from other groups'. We adopted this definition to distinguish communities in this report. Community structure at each site was determined after including only those species that represented $>1 \%$ of the total catch at that site. Frequency, abundance, and dominance (Fager, 1963) were used as community measures to compare species assemblages among the 3 sites. Frequency was calculated by counting the number of samples containing a given species. Abundance was the number of individuals of a species in a sample. Dominance was determined in 2 ways: using counts and biomass. The numerically dominant species at each site were found by summing the abundance of all species in order starting from the species having the highest abundance at each site. Those species included when the summation reached $50 \%$ of the total individuals were considered to be the numerical dominants at the site. The biomass dominants were found similarly.

The species used to examine community structure were also examined to see if there was any relationship with temperature, depth or position. The Kruskal-Wallis test, followed by Dunn's multiple comparison test (KW-D) was used to determine if the abundance differences found with depth, or with temperature (temperature at trawl depth $>16$ or $<16^{\circ} \mathrm{C}$ ) were significantly different. The Mann-Whitney test (MW) was used to determine if the abundance differences for each species found between the inside and outside sites were significantly different. The edge site was omitted from this last comparison because of the lack of samples. A significance level of 0.05 was used for all tests.

\section{Size, reproduction and chemical composition}

Carapace lengths of Sergia prehensilis, Oplophorus spinosus, and Systellaspis debilis were measured $( \pm 0.16 \mathrm{~mm}$ ) from the posterior margin of the orbit to a line perpendicular to the dorsal end of the carapace using an eyepiece micrometer in a Wild M7A stereomicroscope. We compared the size-frequency structure of males and females of each species separately between the 3 domains using the Median Test (MT). The proportions of breeding females, and breeding males of each species in the 3 domains were compared using a contingency table analysis $\left(\chi^{2}\right)$. Fecundity of $O$. spinosus and $S$. debilis was estimated by counting the number of eggs attached to the ventral abdominal surface and pleopods of females and compared among domains (KW-D).

Carbon and nitrogen analyses were done on Oplophorus spinosus and Sergia prehensilis. The frozen samples were thawed, and the sex of 10 individuals of each species was determined, weighed, and measured, refrozen in liquid nitrogen, freeze dried to a constant weight and stored in desiccators. Muscle tissues removed from the first 2 abdominal segments were weighed ( 300 to $1500 \mu \mathrm{g} \pm 1 \mu \mathrm{g}$ ) and analyzed in a Hewlett-Packard model 185B CHN analyzer. Acetanilide and cyclohexanone-2, 4 dinitrophenyl hydrazone were used as standards. The precision of the method was determined by analyzing 17 replicates from one $O$. spinosus. The mean carbon content $( \pm 1$ s.d.) was $41.0 \% \pm 1.1 \%$, and the mean nitrogen content was $13.4 \% \pm 0.4 \%$ of the dry weight of the muscle tissue.

\section{RESULTS}

\section{Eddy structure}

Eddy diameter based on the $15^{\circ} \mathrm{C}$ isotherm at $250 \mathrm{~m}$ depth was about $120 \mathrm{~km}$ (Fig. 3). The eddy moved about $55 \mathrm{~km}$ north-northwest during the study at an average rate of $6 \mathrm{~km} \mathrm{~d}^{-1}$ (Brandt, 1981). We cannot be certain that the eddy was closed during the study because no temperature data were taken from the southern part of the eddy although Tranter et al. (1980b) have shown that Eddy F was closed on the southern perimeter on 18-19 November 1978.

Temperature and salinity profiles to $1100 \mathrm{~m}$ outside, and $2000 \mathrm{~m}$ inside and at the edge of the eddy are shown in Fig. 2. The maximum difference in temperature $\left(4.7^{\circ} \mathrm{C}\right)$ and salinity $(0.47 \%$ ) was at $250 \mathrm{~m}$ between inside and outside the eddy. Salinity and temperature profiles from the eddy edge were most similar to the outside profiles. The major difference in water structure between the 3 domains was the isothermal $\left(17.3\right.$ to $\left.17.6{ }^{\circ} \mathrm{C}\right)$, isohaline $(35.59 \% \mathrm{~S})$ eddy core found between 50 and $290 \mathrm{~m}$ inside the eddy (Fig. 2). There were still substantial differences in temperature $\left(1.5^{\circ} \mathrm{C}\right)$ and salinity $(0.2 \% \mathrm{~S})$ between the outside and edge domains compared with the inside domain at 
Table 2. Abundance of each species for pairs of samples $(3$ samples at $42 \mathrm{~m}$ inside eddy). Numbers represent catches of individuals. Blanks: no specimens caught; single value: specimens caught in only 1 of the trawl samples

\begin{tabular}{|c|c|c|c|c|c|c|c|}
\hline \multirow{3}{*}{$\begin{array}{l}\text { Mean depth }(\mathrm{m}) \\
\text { Mean temperatu }\end{array}$} & \multicolumn{3}{|c|}{ Outside eddy } & Edge & \multicolumn{3}{|c|}{ Inside eddy } \\
\hline & 54 & 151 & 255 & 252 & 42 & 156 & 255 \\
\hline & 17.5 & 13.1 & 12.8 & 15.7 & 18.1 & 17.4 & 17.3 \\
\hline \multicolumn{8}{|l|}{ Decapoda: Caridea } \\
\hline \multicolumn{8}{|l|}{ Family Oplophoridea } \\
\hline Acanthephyra quadrispinosa Kemp 1939 & & 4 & 6 & $1-1$ & & & 3 \\
\hline Oplophorus spinosus (Brulle 1839) & & $37-47$ & $29-38$ & $19-55$ & 14 & $30-54$ & $41-106$ \\
\hline O. novazeelandiae de Man 1931 & & & 3 & 1 & & & \\
\hline Systellaspis debilis (A. Milne Edwards 1813) & & 5 & $5-7$ & $24-26$ & $1-1$ & $39-66$ & $31-59$ \\
\hline \multicolumn{8}{|l|}{ Family Pandalidae } \\
\hline Plesionika sp. & & $1-2$ & & & & 1 & \\
\hline Parapandalas richardi (Coutiere 1905) & & & $1-1$ & 1 & & 2 & \\
\hline \multicolumn{8}{|l|}{ Decapoda: Penaeidea } \\
\hline \multicolumn{8}{|l|}{ Family Penaeidae } \\
\hline \multicolumn{8}{|l|}{ Subfamily Penaeinae } \\
\hline Funchalia villosa (Bouvier 1905) & 1 & 1 & & $2-3$ & $2-36-50$ & $5-9$ & $7-10$ \\
\hline \multicolumn{8}{|l|}{ Subfamily Aristaeinae } \\
\hline Gennadas bouveri Kemp 1909 & & & 1 & 1 & & & \\
\hline G. clavicarpus de Mann 1907 & & & & 3 & & $1-2$ & \\
\hline G. gilchristi Calman 1927 & & 4 & $34-78$ & $2-9$ & & & 2 \\
\hline G. incertus Balss 1927 & & 2 & 1 & 1 & & & \\
\hline G. scutatus Bouvier 1906 & & & 1 & 1 & & & \\
\hline \multicolumn{8}{|l|}{ Decapoda: Sergestidea } \\
\hline \multicolumn{8}{|l|}{ Family Sergestidae } \\
\hline \multicolumn{8}{|l|}{ Subfamily Sergestinae } \\
\hline Sergestes armatus Kroyer 1855 & & $2-11$ & $8-15$ & $1-4$ & 1 & $1-1$ & $1-7$ \\
\hline S. corniculum Kroyer 1855 & & 4 & $2-19$ & $3-9$ & & $2-4$ & $1-3$ \\
\hline S. disjunctus Burkenroad 1940 & & $1-13$ & $17-42$ & $1-1$ & & & $1-1$ \\
\hline S. orientalis Hansen 1919 & & & 1 & $1-2$ & & & 1 \\
\hline S. pectinatus Sund 1920 & & & 1 & 1 & & $1-2$ & $1-1$ \\
\hline S. sargassi Ortmann 1893 & & 1 & & & & 1 & \\
\hline S. seminudus Hansen 1919 & & & 2 & & & & \\
\hline S. stimulator Burkenroad 1940 & & & $1-3$ & $2-2$ & $1-3$ & $5-12$ & $7-8$ \\
\hline Sergia grandis Sund 1920 & & & 2 & & & & \\
\hline S. prehensilis Bate 1881 & & $2-206$ & $115-136$ & $65-76$ & 1. & $10-36$ & $40-44$ \\
\hline S. regalis Gordon 1939 & & & 1 & & & & \\
\hline S. scintillans Burkenroad 1940 & & & $2-3$ & 3 & & $1-2$ & 2 \\
\hline S. splendens Sund 1920 & & & $1-3$ & $1-1$ & & $4-4$ & 1 \\
\hline
\end{tabular}

$1000 \mathrm{~m}$ (Fig. 2). A thermal cross-section of Eddy F and the surrounding Tasman Sea waters to $450 \mathrm{~m}$ depth is given in Brandt (1981). The temperature-salinity diagrams given in Brandt (in press) for the 3 regions show that all sampling was done in a single water mass. However, the substantial differences in temperature with depth, and salinity with depth (Fig. 2) suggest each of the sampling sites was in a different domain within the Tasman Sea water mass.

\section{Abundance, distribution, and community structure}

We caught 2025 individuals belonging to 25 species of carids, penaeids, and sergestids (Table 2). Systellaspis debilis, Funchalia villosa, Gennadas gilchristi, and
Sergestes disjunctus showed abrupt abundance changes between domains, while Acanthephyra quadrispinosa, Sergestes armatus, $S$. corniculum, and $S$. stimulator were approximately equally abundant in all 3 domains (Table 2). Sergia prehensilis and Oplophorus spinosus showed abundance clines across the domain boundaries. The 5 most abundant species were Sergia prehensilis $(36.0 \%$ of the total catch), Oplophorus spinosus $(23.2 \%)$ Systellaspis debilis $(13.0 \%)$ Gennadas gilchristi $(6.4 \%)$ and Funchalia villosa $(6.2 \%)$.

The 11 species found in abundances greater than $1 \%$ of the total at any one site are given in Table 3 . When species counts from the same depths inside and outside the eddy were combined, the abundance of 
Table 3. Percent composition of abundant species $1>1 \%$ of total number at each site) outside, inside and at the edge of Eddy $F$

\begin{tabular}{|c|c|c|c|}
\hline \multirow[t]{2}{*}{ Species } & \multicolumn{3}{|c|}{ Percent of total } \\
\hline & $\begin{array}{l}\text { Outside } \\
\text { eddy }\end{array}$ & $\begin{array}{l}\text { Eddy } \\
\text { edge }\end{array}$ & $\begin{array}{l}\text { Inside } \\
\text { eddy }\end{array}$ \\
\hline Sergestes disjunctus ${ }^{\mathrm{O} . \mathrm{C}}$ & 7.8 & & \\
\hline Acanthephyra quadrispinosa ${ }^{\mathrm{C}}$ & 1.1 & & \\
\hline Gennadas gilchristi $^{\mathrm{C}}$ & 12.6 & 3.4 & \\
\hline Sergia prehensilis ${ }^{\mathrm{C}}$ & 49.6 & 43.7 & 16.8 \\
\hline Oplophorus spinosus & 16.4 & 22.9 & 31.4 \\
\hline Systellaspis debilis' & 1.8 & 15.5 & 25.1 \\
\hline Sergestes armatus ${ }^{\mathrm{C}}$ & 3.9 & 1.5 & 1.4 \\
\hline Sergestes comiculum & 2.7 & 1.5 & 1.3 \\
\hline Funchalia villosa. w & & 1.5 & 15.2 \\
\hline Sergestes stimulator & & 1.2 & 4.5 \\
\hline Sergia splendens & & & 1.2 \\
\hline Total number of individuals & 921 & 323 & 781 \\
\hline \multicolumn{4}{|c|}{$\begin{array}{l}\text { O: outside species; }{ }^{1} \text { : inside species; }{ }^{C} \text { : cold-water speries; } \\
\text { w: warm-water species }\end{array}$} \\
\hline
\end{tabular}

Oplophorus spinosus, Systellaspis debilis, Sergestes armatus, S. corniculum, S. disjunctus, and S. prehensilis increased with increasing depth (KW-D). Acanthephyra quadrispinosa, G. gilchristi, S. armatus, S. disjunctus, and S. prehensilis were significantly more abundant in cold water $\left(<16^{\circ} \mathrm{C}\right)$, while Funchalia villosa was significantly more abundant in warm $\left(>16^{\circ} \mathrm{C}\right)$ water (MW). Using only the inside and outside samples, $S$. debilis, $F$. villosa, and $S$. stimulator were more abundant inside the eddy, while $S$. disjunctus was more abundant outside (MW). A comparison between the $250 \mathrm{~m}$ samples from each domain showed that $S$. debilis and $F$. villosa were more abundant inside and $S$. prehensilis was more abundant outside the eddy (KW-D). There was a significant difference in penaeid biomass (MW, Table 1) between inside and outside sites. No other significant biomass differences among sites or between depths in the 3 families were found (Table 1). There were separate communities inside and outside the eddy, and although the edge site was intermediate in species composition (Table 3) it was considered a separate community. $S$. disjunctus and $A$. quadrispinosa were abundant only outside, and Sergia splendens was abundant only inside the eddy. Gennadas gilchristi was common outside and at the edge, while F. villosa and $S$. stimulator were common both inside and at the eddy edge. The remaining 5 species were present in abundances $>1 \%$ of the total at each of the 3 sites.
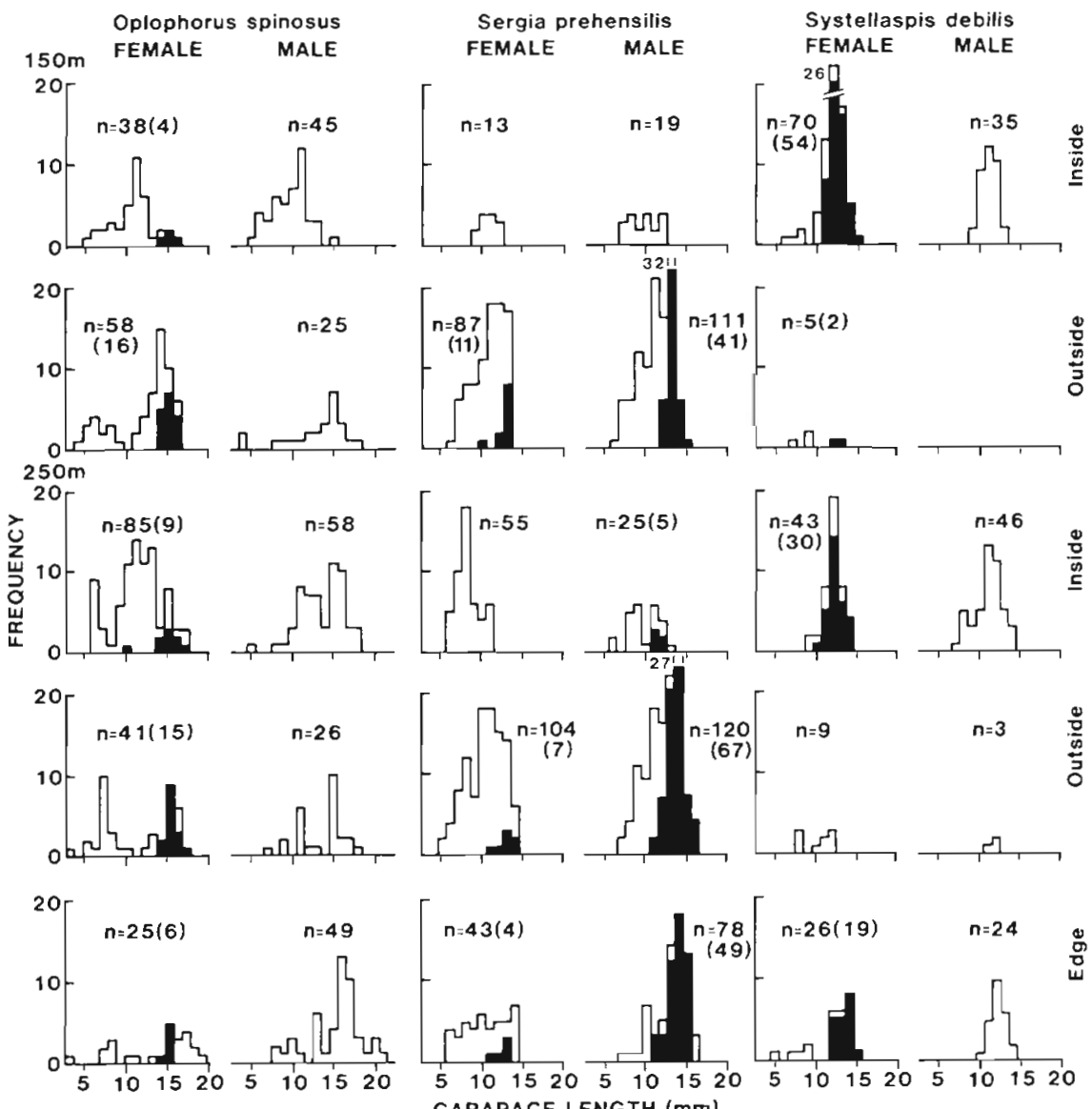

Fig. 4. Oplophorus spinosus, Sergia prehensilis and Systellaspis debilis. Carapace-length frequency distributions of females and males caught at $150 \mathrm{~m}$ inside and outside the eddy, and at $250 \mathrm{~m}$ at all 3 sampling sites. $n$ : total number measured; numbers breeding (solid bars) in parentheses 
Table 4. Oplophorus spinosus and Systellaspis debilis. Comparison of ovigerous females outside, at edge and inside Eddy $F$

\begin{tabular}{|c|c|c|c|c|c|c|}
\hline & \multicolumn{3}{|c|}{ Oplophorus spinosus } & \multicolumn{3}{|c|}{ Systellaspis debilis } \\
\hline & Outside & Edge & Inside & Outside & Edge & Inside \\
\hline Number of ovigerous females & 31 & 6 & 13 & 2 & 10 & 84 \\
\hline Percent of total & 20.5 & 8.1 & 5.3 & 8.7 & 37.2 & 42.9 \\
\hline Carapace length (mean \pm 1 s.d.) & $15.4 \pm .8$ & $15.1 \pm .5$ & $15.1 \pm 1.0$ & $12.8 \pm$ & $13.2 \pm 1.0$ & $13.0 \pm 1.0$ \\
\hline range & $14.0-17.7$ & $14.5-15.8$ & $10.0-17.3$ & $12.5-13.2$ & $12.3-15.0$ & $11.3-15.8$ \\
\hline Egg count (mean \pm 1 s.d.) & $23.9 \pm 7.7$ & $20.7 \pm 6.5$ & $17.9 \pm 8.0$ & $10.5 \pm 3.5$ & $13.3 \pm 3.9$ & $13.8 \pm 3.8$ \\
\hline range & $6-36$ & $10-29$ & $3-30$ & $8-13$ & $6-19$ & $2-23$ \\
\hline
\end{tabular}

The numerical dominants outside the eddy were Sergia prehensilis and Gennadas gilchristi while $S$. prehensilis and Oplophorus spinosus were the dominants at the eddy edge. Oplophorus spinosus and Systellaspis debilis were the numerical dominants inside the eddy. The biomass dominants outside the eddy were $S$. prehensilis $(47.9 \%$ of the total crustacean biomass outside the eddy; Table 1 ) and $O$. spinosus $(31.0 \%)$, while O. spinosus $(34.2 \%)$ and $S$. debilis (30.5\% were the biomass dominants at the eddy edge. Funchalia villosa $(35.7 \%)$ and 0 . spinosus $(28.0 \%)$ were the biomass dominants inside the eddy.

\section{Size, reproduction and chemical composition}

We compared size, reproductive condition, and chemical composition of the 3 most abundant species among sites, and the chemical composition of Sergia prehensilis and Oplophorus spinosus from $250 \mathrm{~m}$ among sites. Juveniles of $S$. prehensilis, $O$. spinosus and Systellaspis debilis were found at all sampling sites.

Sergia prehensilis was larger outside than inside the eddy (MT). For all samples combined median sizes of females and males were $12 \mathrm{~mm}$ and $11 \mathrm{~mm}$ respectively outside the eddy and $9 \mathrm{~mm}$ for both sexes inside the eddy. At $250 \mathrm{~m}$, the outside and edge females (11 $\mathrm{mm}$ and $10 \mathrm{~mm}$ ) and males $(13 \mathrm{~mm}$ and $14 \mathrm{~mm}$ ) were significantly larger than females $(8 \mathrm{~mm})$ and males $(9 \mathrm{~mm})$ inside the eddy and showed several cohorts (Fig. 4). Proportionately more breeding males were found outside and at the edge than inside the eddy $\left(\chi^{2}\right)$ and no breeding females were caught inside Eddy $\mathrm{F}$ (Fig. 4). Carbon levels and $\mathrm{C} / \mathrm{N}$ ratios were higher in $S$. prehensilis at the eddy edge than elsewhere (Fig. 5); the chemical composition of this species inside and outside the eddy did not differ (KW-D).

Oplophorus spinosus was significantly larger outside than inside Eddy F (MT). Median sizes of both males and females were $13 \mathrm{~mm}$ outside the eddy and $11 \mathrm{~mm}$ inside. At $250 \mathrm{~m}$, specimens of both sexes caught at the eddy edge had a median size of $15 \mathrm{~mm}$ and were larger than outside $(13 \mathrm{~mm})$ and inside $(11 \mathrm{~mm})$ specimens. Females had a bimodal (juvenile and adult) length frequency distribution outside the eddy which was less apparent than in other domains or in males (Fig. 3). Proportionately more females were breeding $\left(\chi^{2}\right)$ and mean egg count was higher (KW-D) outside the eddy than inside or at the eddy edge (Table 4). Carbon levels and $C / N$ ratios were higher at the eddy edge (Fig. 4) than elsewhere (KW-D).

At $250 \mathrm{~m}$, female Systellaspis debilis were larger at the eddy edge $(13 \mathrm{~mm})$ than inside $(12 \mathrm{~mm})$ or outside

Fig. 5. Oplophorus spinosus and Sergia prehensilis. Carbon and nitrogen $(\%$ of dry weight in freeze-dried muscle tissue) of individuals caught outside, inside and at edge eddy. Mean \pm 1 s.d. carbon in $O$. spinosus was $39.9 \pm 1.0 \%$ outside, $39.1 \pm 1.4 \%$ inside, and $43.8 \pm 2.0 \%$ at the eddy edge; mean nitrogen levels were $12.5 \pm 1.0 \%$ outside $13.1 \pm 0.6 \%$ inside, and $13.2 \pm 1.3 \%$ at the eddy edge. In S. prehensilis carbon levels were $40.6 \pm 1.8 \%$ outside, $40.2 \pm 2.0 \%$ inside, and $46.1 \pm 2.4 \%$ at the edge; nitrogen levels were $12.5 \pm 0.7 \%$ outside, $12.7 \pm 0.6 \%$ inside, and $13.1 \pm 1.0 \%$ at the edge

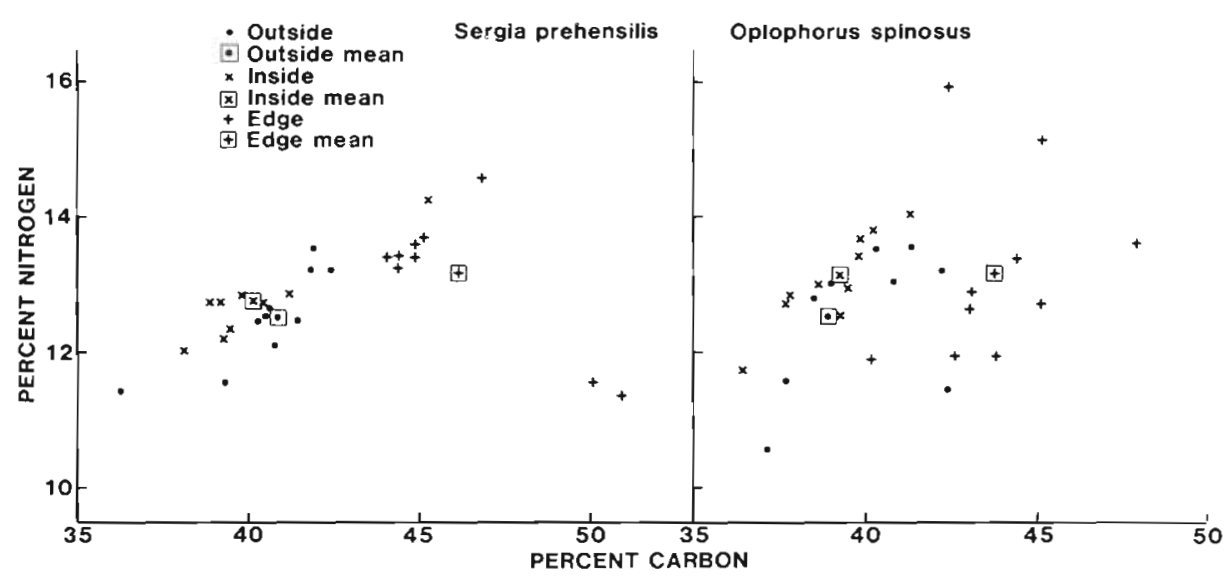


$(11 \mathrm{~mm})$ the eddy (MT). Males did not differ in size among sites (Fig. 3). Proportionately more females were breeding inside the eddy and at the eddy edge than outside $\left(\chi^{2}\right)$. Breeding size and fecundity did not differ among sites (Table 4, KW-D).

\section{DISCUSSION}

Sampling was limited to a single cruise, and by a small number of samples (Brandt, 1981). Our sampling design also assumed that each animal maintained a constant depth throughout the night. Sampling biases among sites may have resulted from the continuous migration of individuals through the night (Roe, 1974), size stratification with depth (Omori, 1969; Donaldson, 1975; Walters, 1976) and the effects of moon phase on vertical migration patterns (Walters, 1976). Our study was not designed to investigate these questions, and the consistency of the results suggests that the differences in crustacean communities among domains were not due entirely to such sampling biases. As far as is known, all of the species recorded in this study live at depths greater that $600 \mathrm{~m}$ by day and migrate to above $300 \mathrm{~m}$ at night (Foxton, 1970a, b; Roe, 1974; Donaldson, 1975; Walters, 1976).

Crustacean species assemblages differed across the Eddy F boundary. Seven of the 11 abundant species showed abrupt or clinal changes in abundance across domains analogous to the patterns across water mass boundaries shown by mesopelagic fish, crustaceans, and squid (McGowan, 1971; Jahn and Backus, 1976; Robertson et al., 1978; Fasham and Foxton, 1979; Brandt, 1981, in press). Brandt (1981) found distinct fish communities in each domain in and around Eddy $F$. Several fish species were dominant only at the edge of Eddy F, although no crustacean species showed this pattern. Some fish may have a more restricted habitat preference, and a better ability to select and maintain their position in the dynamic eddy edge region compared with Crustacea. Squid community structure also corresponded to Eddy F location and water temperature, although the patterns were not as distinct as for fish and Crustacea (Brandt, in press). The 3 Tasman Sea domains are basically indistinguishable on temperature-salinity relationships (Brandt, in press) but differ considerably in the distribution of temperature, and of salinity, with depth. We suggest that the distributions of Crustacea among the 3 domains are related, directly or indirectly, to differences in the vertical physical-chemical structure of the three different domains.

The 3 most abundant crustaceans, Sergia prehensilis, Oplophonus spinosus, and Systellaspis debilis were widespread, but differed in size, fecundity, and percentage of breeding animals among domains.
These species have a 1 to 3 yr life span (Omori, 1974) and Eddy $F$ was 6 to 10 mo old by December 1978 (Boland and Church, 1981). This period may be a sufficiently long exposure to an altered physical and biological environment to affect life history characteristics. Wiebe and Boyd (1978) and Boyd et al. (1978) found notable changes in abundance, sex ratios, and chemical composition of the euphausid Nematoscelis megalops trapped in cold core rings for a similar period. The general lack of baseline life history studies on these mesopelagic crustaceans in the Tasman Sea limits our ability to determine what caused the differences. For example, size differences across domains could be due to different breeding times or growth rates, and these in turn may be influenced by differences in environmental temperature or food availability among domains. The presence of juveniles of all 3 species suggests these crustaceans reproduced in each domain as there is Iittle evidence of extensive physical mixing between one domain and another (Scott, 1978).

To estimate the potential importance of temperature in contributing to size differences, a mean habitat temperature' was calculated for migrating Crustacea in each domain using data from Fig. 2 and assuming that an average animal spent $8 \mathrm{~h}$ at $200 \mathrm{~m}$ (night), $12 \mathrm{~h}$ at $750 \mathrm{~m}$ (day) and $4 \mathrm{~h}$ vertically migrating. The mean habitat temperatures were $9.6^{\circ} \mathrm{C}$ outside, $10.2^{\circ} \mathrm{C}$ at the eddy edge, and $12.4^{\circ} \mathrm{C}$ inside Eddy $\mathrm{F}$ in December 1978. Sergestid and euphausid growth rates have been shown to differ significantly with temperature differences of 3 to $4{ }^{\circ} \mathrm{C}$ (Lasker, 1966; Omori, 1971, 1979; Ross, 1981). Thus the thermal contrasts could be sufficient to contribute to the size differences seen between crustaceans caught inside and outside the eddy.

Temperature may affect the breeding cycle as well. Omori et al. (1974, quoted in Omori and Gluck, 1979) have shown that spawning times and larval survival of Sergia lucens are more closely related to ambient temperature than food abundance. There is no evidence that fecundity in mesopelagic Crustacea is affected by either temperature or food availibility although Omori (1974) found that fecundity is usually greater in larger females. A time-series study would be necessary for a comparison of growth rates, fecundity and breeding seasons among the 3 domains; with a single cruise we can only highlight differences observed.

Growth rates of Crustacea can also vary in response to food quality and quantity (Omori, 1970; Ikeda, 1971; Boyd et al., 1978; Ross, 1981). There is some evidence that potential food resources for Crustacea did vary across the Eddy F boundary. Tranter et al. (1980a) have shown the spring phytoplankton bloom occurred 1 mo later inside Eddy $F$ than outside. Tranter et al. (in press) found differences in copepod species distribu- 
tion, but not biomass, between inside and outside Eddy F. Brandt (1982) found some myctophid fish were feeding on salps outside, but not inside the eddy, apparently in response to the increased salp abundance outside Eddy F. These differences in food resources may also contribute to differences in the growth and reproduction of crustaceans.

The higher tissue carbon levels found in Oplophorus spinous and Sergia prehensilis at the eddy edge suggest that some enhancement of physiological condition has occurred compared to the other 2 regions. A number of studies (Uda, 1959; Pingree et al., 1976; Savidge, 1976; Fourier, 1978; Simpson and Pingree, 1978; Iverson et al., 1979; Floodgate et al., 1981) have shown increased phytoplankton and zooplankton levels at oceanic fronts. If this also occurred at the eddy edge, phytoplankton and zooplankton concentrations may accelerate growth rates and improve the condition of animals further up the food chain. Boyd et al. (1978) have argued that reduced levels of tissue carbon found in Nematoscelis megalops in cold core rings were due to starvation. Perhaps the increase in tissue carbon found in our study may be due to increased food abundance at the eddy edge relative to the other areas. Tranter et al. (1980a) has shown the Eddy F edge had consistently larger phytoplankton standing stocks between September and December 1978; but the evidence for higher zooplankton biomass in this region is not as clear.

In summary, different crustacean communities were found outside, inside, and at the edge of warm-core Eddy F. The inside community may represent a community trapped when the eddy separated from the EAC. Eddy populations of cosmopolitan species showed abundance differences, changed size-frequency distributions, fecundity, and propartion of breeding individuals compared to edge, and outside populations. These differences may be caused, at least in part, by differences in the physical, chemical, and biological habitats in the 3 domains. Warm-core eddies may thus present a unique opportunity to study the effects of altered environments on oceanic micronekton species and communities.

Acknowledgements. We wish to thank R. Cowper, D. J. Tranter, K. Trenorden, and $\mathrm{K}$. Williams and the Captain and crew of the FRV Courageous for invaluable help at sea; and especially C. Lanzing for sorting the samples, and to B. Kensley for confirming some of the sergestid identifications.

\section{LITERATURE CITED}

Andrews, J. C., Scully-Power, P. (1976). The structure of an East Australian Current anticyclonic eddy. J. phys. Oceanogr. 6: 756-765
Boland, F. M. (1973). A monitoring section across the East Australian Current. Tech. Pap. Div. Fish. Oceanogr C.S.I.R.O. Aust. 34: 1-9

Boland, F. M., Church, J. A. (1981). The East Australian Current, 1978. Deep Sea Res. 28: 937-957

Boyd, S. H., Wiebe, P. H., Cox, J. L. (1978). Limits of Nematoscelis megalops in the northwestern Atlantic in relation to Gulf Stream cold-core rings. Part II. Physiological and biochemical effects of expatriation. J. mar. Res. 36: 143-159

Brandt, S. B. (1981). Effects of a warm-core eddy on fish distributions in the Tasman Sea off East Australia. Mar Ecol. Prog. Ser. 6: 19-33

Brandt, S. B. (in press). Water mass affiliations of cephalopods in relation to a warm-core eddy in the Tasman sea. Aust. J. mar. Freshwat. Res. 34

Brandt, S. B., Wadley, V. A. (1981). Thermal fronts as ecotones and zoogeographic barriers in marine and freshwater systems. Proc. Ecol. Soc. Aust. 11: 13-26

Bruce, J. G. (1979). Eddies of the Somali coast during the southwest monsoon. J. geophys. Res. 84: 7742-7748

Crosnier, A., Forest, J. (1973). Les crevettes profondes de Atlantique Oriental Tropical. Faune Trop. 19: 1-409

Dodimead, A. J., Favorite, F., Hirano, T. (1963). Salmon of the North Pacific Ocean Part II. Review of oceanography of the subarctic Pacific region. Bull. int. N. Pacif. Fish. Commn. 13: $1-195$

Donaldson, H. A. (1975). Vertical distribution and feeding of sergestid shrimps (Decapoda: Natantia) collected near Bermuda. Mar. Biol. 31: 37-50

Fager, E. W. (1963). Communities of organisms. In: Hill, N. M. (ed.) The sea, Vol. 2. Interscience, New York, p. 415-437

Fasham, M. J. R., Foxton, P. (1979). Zonal distribution of pelagic decapoda (Crustacea) in the eastern North Atlantic and its relation to the physical oceanography. J. exp. mar. Biol. Ecol. 37: 225-253

Floodgate, G. D., Fogg, G. E., Jones, D. A., Lochte, K., Turley, C. M. (1981). Microbiological and zooplankton activity at a front in Liverpool Bay. Nature, Lond. 290: 133-136

Fourier, R. O. (1978). Biological aspects of the Nova Scotia shelf-break fronts. In: Bowman, M. J., Esaias, W. E. (eds.) Oceanic fronts in coastal processes. Springer-Verlag, New York, p. 69-77

Foxton, P. (1970a). The vertical distribution of pelagic decapods (Crustacea: Natantia) collected on the Sond cruise 1965. I. The Caridea. J. mar. biol. Ass. U.K. 50: 939-960

Foxton, P. (1970b). The vertical distribution of pelagic decapods (Crustacea: Natantia) collected on the Sond cruise 1965. II. The Penaeidea and general discussion. J. mar. biol. Ass. U.K. 50: 961-1000

Fuglister, F. C. (1972). Cyclonic rings formed by the Gulf Stream 1965-66. In: Gordon, A. (ed.) Studies in physical oceanography. New York, p. 137-168

Hamon, B. V. (1965). The East Australian Current, 1960-1964. Deep Sea Res. 12: 899-921

Ikeda, $\Upsilon$ (1971). Changes in respiration rate and in composition of organic matter in Calanus cristatus (Crustacea Copepoda) under starvation. Bull. Fac. Fish. Hokkaido Univ. 21: 280-298

Iverson, R. L., Coachman, L. K., Cooney, R. T., English, T S., Goering, J. J., Hunt, G. L. Jr., Macauley, M. C., McRay, C. P., Reeburg, W. S., Whitledge, T. E. (1979). Ecological significance of fronts in the southeastern Bering Sea. In: Livingston, R. J. (ed.). Ecological processes in coastal and marine systems. Plenum Press, New York, p. 437-466

Jahn, A. E., Backus, R. H. (1976). On the mesopelagic fish 
faunas of Slope Water, Gulf Stream, and northern Sargasso sea. Deep Sea Res. 23: 223-234

Jeffrey, S. W., Hallegraeff, G. M. (1980). Studies of phytoplankton species and photosynthetic pigments in a warmcore eddy of the East Australian current. I. Summer populations. Mar. Ecol. Prog. Ser. 3: 285-294

Kensley, B. F. (1968). Deep sea decapod crustacea from west of Cape Point, South Africa. Ann. S. Afr. Mus. 50: 283-323

Kensley, B. F. (1971a). The family Sergestidae in the waters around southern Africa. Ann. S. Afr. Mus. 57: 215-264

Kensley, B. F. (1971b). The genus Gennadas in the waters around southern Africa. Ann. S. Afr. Mus. 57: 271-294

Kensley, B. F. (1972). Shrimps and prawns of southern Africa. South African Museum, Capetown

Lasker, R. (1966). Feeding, growth, respiration and carbon utilization by a Euphausiid crustacean. J. Fish. Res. Bd Can. 23: 1291-1317

McGowan, J. A. (1971). The nature of oceanic ecosystems. In: Miller, C. B. (ed.) The biology of oceanic Pacific. Oregon State University, Corvallis, p. 9-28

Mills, E. L. (1969). The community concept in marine ecology, with comments on continuity and instability in some marine communities. J. Fish. Res. Bd Can. 26: 1415-1428

Nilsson, C. S. (1977). Measurement of surface currents around an eddy (U). R. Aust. Navy, Res. Lab. Tech. Note 5/77: $1-17$

Nilsson, C. S., Andrews, J. C., Hornibrook, M., Lathan, A. R., Speechley, G., Scully-Power, P. (1982). High resolution satellite observations of mesoscale oceanography in the Tasman Sea 1978-1979. Final Report Project HCM-OSI. R. Aust. Navy, Res. Lab. Rep. 1/82

Nilsson, C. S., Cresswell, G. R. (1981). The formation and evolution of East Australian Current warm-core eddies. Prog. Oceanogr. 9: 134-183

Omori, M. (1969). The biology of a sergestid shrimp Sergestes lucens Hansen. Bull. Ocean Res. Inst. Univ. Tokyo 4: 1-83

Omori, M. (1970). Variations of length, weight, respiratory rate, and chemical composition of Calanus cristatus in relation to its food and feeding. In: Steele, J. H. (ed.) Marine food chains. Oliver and Boyd, Edinburgh, p. 113-126

Omori, M. (1971). Preliminary rearing experiments on the larvae of Sergestes lucens (Penaeidea, Natantia, Decapoda). Mar. Biol. 9: 228-234

Omori, M. (1974). The biology of pelagic shrimps in the ocean. In: Russell, F. S., Yonge, M. (eds.) Advances in marine biology, Vol. 12. Academic Press, London, p. 233-324

Omori, M. (1979). Growth, feeding and mortality of larval and early post-larval stages of the oceanic shrimp Sergestes similis Hansen. Limnol. Oceanogr. 24: 273-288

Omori, M., Gluck, D. (1979). Life history and vertical migration of the pelagic shrimp Sergestes similis off the southern California coast. Fish. Bull. Fish Wildl. Serv. U.S. 77 : 183-198

Ortner, P. B., Hulburt, E. M., Wiebe, P. H. (1979). Phytohydrography, Gulf Stream rings, and herbivore habitat contrasts. J. exp. mar. Biol. Ecol. 39: 101-124

Ortner, P. D., Wiebe, P. H., Haury, L. R., Boyd, S. H. (1978). Variability in zooplankton biomass distribution in the northern Sargasso Sea: the contribution of Gulf Stream cold-core rings. Fish. Bull. Fish Wildl. Ser. U.S. 76 : $323-334$

Pingree, R. D., Holligan, P. M., Mardell, G. T., Head, P. N.
(1976). The influence of physical stability on spring, summer and autumn phytoplankton blooms in the Celtic Sea. J. mar. biol. Ass. U.K. 56: 845-873

Ring Group, The (1981). Gulf Stream cold core rings: their physics, chemistry, and biology. Science, N. Y. 212: $1091-1100$

Robertson, D. A., Roberts, P. E., Wilson, J. B. (1978). Mesopelagic faunal transition across the subtropical convergence east of New Zealand. N. Z. Jl mar. Freshwat. Res. 12: 295-312

Roe, H. S. J. (1974). Observations on the diurnal vertical migration of an oceanic animal community. Mar. Biol. 28: 99-113

Ross, R. M. (1981). Laboratory culture and development of Euphausia pacifica. Limnol. Oceanogr. 26: 235-246

Savidge, G. (1976). A preliminary study of the distribution of chlorophyll $a$ in the vicinity of fronts in the Celtic and western Irish seas. Estuar. coast. mar. Sci. 4: 617-625

Scott, B. D. (1978). Hydrological features of a warm-core eddy and their biological implications. Rep. Div. Fish. Oceanogr. C.S.I.R.O. Aust. 100

Simpson, J. H., Pingree, R. D. (1978). Shallow sea fronts produced by tidal stirring. In Bowman, M. J., Esaias, W. E. (eds). Oceanic fronts on coastal processes. Spring-Verlag, New York, p. 29-42

Tomosada, S. (1978). A large warm eddy detached from the Kuroshio east of Japan. Bull. Tokai reg. Fish Res. Lab. 94 : 59-103

Tranter, D. J., Parker, R. R., Cresswell, G. R. (1980a). Are warm-core eddies unproductive? Nature, Lond. 284: 540-542

Tranter, D. J., Parker, R. R., Gardner, D., Campbell, R. (1980b). In vivo chlorophyll a fluorescence in the vicinity of warm-core eddies off the coast of New South Wales 3. November 1978. Rep. Div. Fish. Oceanogr. C.S.I.R.O. Aust. 112: 1-27

Tranter, D. J., Parker, R. R., Higgins, H. W. (1979). In vivo chlorophyll a fluorescence in the vicinity of warm-core eddies off the coast of New South Wales 2. October 1978. Rep. Div. Fish. Oceanogr. C.S.I.R.O. Aust. 110

Tranter, D. J., Tafe, D. J., Sandland, R. L. (in press). Some zooplankton characteristics of warm-core eddies shed by the East Australian Current, with particular reference to copepods. Aust. J. mar. Freshwat. Res. 34

Uda, M. (1959). Water mass boundaries - 'siome' frontal theory in oceanography. Fisheries Research Board of Canada. Manuscript Report Section 51 (unpubl.)

Walters, J. F. (1976). Ecology of Hawaiian sergestiid shrimp (Penaeidea: Sergestidae). Fish. Bull. U.S. 74: 799-836

Wiebe, P. H., Boyd, S. H. (1978). Limits of Nematoscelis megalops in the northwestern Atlantic in relation to Gulf Stream cold-core rings. Part I. Horizontal and vertical distributions. J. mar. Res. 36: 119-142

Wiebe, P. H. Flierl, G. R. (in press). Euphausiid invasion/ dispersal in Gulf Stream cold-core rings. Aust. J. mar. Freshwat. Res. 34

Wiebe, P. H., Hulbert, E. M., Carpenter, E. J., Jahn, A. E., Knapp, G. P., Boyd, S. B., Ortner, P. B., Cox, J. L. (1976). Gulf Stream cold core rings: large scale interaction sites for open-ocean plankton communities. Deep Sea Res. 23: $695-710$

Yaldwyn, J. C. (1957). Deep-water crustacea of the genus Sergestes (Decapoda, Natantia) from Cook Strait, New Zealand. Victoria University of Wellington 22: 1-27 